\title{
Covid-19 and the power of rules
}

\author{
Malcolm Brady ${ }^{1}$ (D)
}

Received: 4 September 2020 / Accepted: 10 January 2021 / Published online: 27 January 2021 (C) Springer Nature Switzerland AG 2021

\begin{abstract}
This article discusses the role of human-created rules in our collective adapting to Covid-19 and our survival in its wake. Rules that make sense become institutionalised and play a dual role in our response to the pandemic: they provide a guide for individual behavior and they provide a mechanism for coordinating all our behaviors.
\end{abstract}

Keywords Covid-19 $\cdot$ Rules $\cdot$ Institutions $\cdot$ Guidance $\cdot$ Coordination $\cdot$ Behavior

This short paper examines the role played by rules and institutions in our collective response to Covid-19. The paper takes a personal experience of the author in institutionalising a new rule and reflects on this in the light of institutional and game theory. The paper suggests that our continued success in managing the pandemic will depend on our ability to create institutions that make sense and are collectively adopted. The paper queries the long-run viability of the distancing rule.

In the last week of May 2020, during phase one of Ireland's relaxation of the Covid-19 lockdown restrictions, I met my daughter for the first time in over two months. We met out of doors in the middle of the Phoenix park in Dublin city. We didn't hug or touch each other and kept apart for the entire time that we were

This note belongs to the Topical Collection "Seeing Clearly Through COVID-19: Current and future questions for the history and philosophy of the life sciences", edited by G. Boniolo and L. Onaga.

Malcolm Brady

malcolm.brady@dcu.ie

1 Business School, Dublin City University, Glasnevin Campus, Dublin 9, Ireland 
together. I had anticipated that this was the way it was going to be and I had expected it to be a very strange experience, indeed part of me had been dreading it. The bond between father and daughter is very strong. ${ }^{1}$ Overcoming the natural human tendency to be physically close ${ }^{2}$ was going to be difficult. That we kept apart demonstrates the power of rules within human society. While this story is mine, this power of rules to force people apart currently applies to people all over the globe: grandchildren are being kept away from grandparents, siblings from each other, parents from their adult children, friends are keeping apart, and people generally are staying away from each other in the streets, in the shops, in the parks.

We met outdoors and kept two meters apart because this was the behaviour specified by the authorities. ${ }^{3}$ However, there was another consideration. Not only did the rules overcome our natural human tendency they also overcame our reasoning. Let me explain. When I met my daughter in the first week after lockdown I knew almost for sure that I did not have the virus: I had met no one outside of my immediate household for ten weeks, well over the specified 14 days required to be clear of the virus, and at no stage during this period had I displayed any symptoms of Covid-19. Similarly, my daughter was almost certainly free of the virus given the long lockdown period and her absence of symptoms. This was the most certain that either of us could be that we were both virus-free. It was therefore highly unlikely that had we hugged we would have transmitted the virus to each other. And yet we stayed apart. Why was this so? It was not because of enforcement of the guidelines by the authorities: there were no Gardai ${ }^{4}$ nearby. It was not because of social or peer pressure: we were far away from other people. It was because we believed that the rules made sense. ${ }^{5}$

The rules made sense because our meeting together was not likely to be a once-off event; we each anticipated that it would be repeated. We also each anticipated that we would meet up with many other people - friends, family, colleagues - during the future phases of relaxation of restrictions. We could each reason that, over time, we would meet up with more and more people, each of whom in turn would have met up with more and more people. The network of interconnections with people will increase exponentially over time, and therefore there is a possibility that eventually one of us will meet up with someone who has the virus and in turn pass it on to the other, and by extension to that person's entire household. If we all will have kept our

\footnotetext{
1 Given the personal nature of some elements of this paper a short note on the positionality of the author is in order. I am male and a lecturer in business strategy with a background in game theory and institutional economics. While this paper was stimulated by my personal experience during the national response to the Covid-19 pandemic in Ireland it was also informed by my academic background. I thank the peer reviewer for bringing to my attention the importance of making positionality clear.

${ }^{2}$ Gordon (1991) suggests that one of the five types of sociality is 'gregariousness': 'the apparent preference of members of some species for physical closeness' (p. 4).

3 The guidance from the Irish authorities during the lockdown included: to stay at home, to keep a twometer distance from each other if you had to go outside, to wash hands regularly, to cough into elbows, to avoid touching your face, and to self-isolate should we show symptoms of Covid-19.

4 Police in Ireland are called Gardaí (singular: Garda).

5 Searle (2005) refers to rules that are followed even in the absence of physical or other overt signals as 'status functions'; he regards these status functions as 'the glue that holds human society together' (p. 9).
} 
distance throughout this entire series of meetings, then there is a lower likelihood that the virus will be transmitted. However, if fewer and fewer of us will have kept our distance, then there is increasing risk of the virus propagating at some future point in time. It is therefore in all our interests to maintain our distance until the virus is extinguished. This process of thinking forward and reasoning backwards ${ }^{6}$ led us both, at our first meeting, to stay apart. The same logic applies to all meetings between myself and anyone else from any other household for the foreseeable future. Indeed, the same logic applies to all meetings between people from different households for the foreseeable future.

This is a very strong rule. While it may stave off immediate disaster it will have great, even potentially catastrophic, consequences for individuals and for society should it apply in its absolute form for an extended period of time. Application of the rule may lead in time to the extinguishing of the virus, but in the short run it has led to drastic curtailment of economic, social and cultural life on earth. Development of an effective and widely-available vaccine ${ }^{7}$ against coronavirus may lead to the rule becoming redundant. Extinguishing of the virus through distancing or other human devices may lead to the rule becoming redundant. But, should the virus remain and the distancing rule be applied indefinitely, the logical conclusion is that no new households could form. The species itself would come under threat: we are threatened by the virus, but also potentially by the remedy. It is therefore likely that at some point in the future the distancing rule will in practice be modified from its absolute form. ${ }^{8}$ We will likely see a merging of extant cultural, social, sexual and economic practices with the new Covid-19 institutions. What these will look like in the long run we do not know but we have some indications from changes that have already taken place: football being played in empty stadia to TV audiences, aggregated online musical performances, avoidance of public transport, queues outside shops, increasing levels of online purchasing with postal delivery, homes becoming offices, offices becoming empty, a return to walking and cycling for leisure and for transport, a rediscovery of local attractions. Even if Covid-19 disappears some of these new, or rediscovered old, institutions will likely remain.

There are a number of reasons why as a population we have largely to date kept the new Covid-19 rules. The rules have power if they make sense ${ }^{9}$ to us individually: we will then use them to guide our personal behaviour. The rules have power if they make sense to us collectively: we will adopt them to coordinate our interactions and mitigate social awkwardness. As they continue to make sense to us individually and collectively they will gradually become institutionalised, ${ }^{10}$ becoming part

\footnotetext{
${ }^{6}$ This thinking process is known as backward induction. See Dixit et al. (2021, p. 55) for an explanation.

7 Several promising vaccine trials were reported in the media in November 2020.

${ }^{8}$ For example, in the second lockdown in Ireland the guidelines were extended to allow people living alone to group into 'social bubbles'. Roberts (2020) discusses support bubbles-within which people do not have to physically distance-in the UK. The institution of support bubbles will allow new households to emerge from the Covid-19 crisis.

9 See Weick (1993) for a discussion of sense-making.

10 See North (1990) for a discussion of institutions as 'the rules of the game in a society ... the humanly devised constraints that shape human interaction' (p. 3).
} 
of our normal behaviour. The new rules will combine with existing cultural, social, economic, educational and health institutions to form new routines that in time will themselves become institutionalised. ${ }^{11}$

The rules also have power if we are coerced into following them through fear or force. We obeyed the rules during the lockdown for fear of rampant spreading of the virus and the consequences of that on human life in general and on the hospital system in particular. The spectre of Italy haunted our collective psyche. ${ }^{12}$ Enforcement of the rules by the authorities has to date played only a small role in Ireland (although this has not been so in all countries; and indeed in Ireland the rules may be more strictly enforced at some time in the future should the authorities deem it necessary ${ }^{13}$ ). During the lockdown people accepted the importance of isolation of households and individuals. During the gradual relaxation of the restrictions people have largely accepted the importance of social distancing and restrictions on travel. Where guidance has been ambiguous, as for example regarding the use of masks, adoption has been less complete. Where guidance is clear but has been challenged, as for example the two-meter specification for social distance, adoption has become less precise over time.

The virus is still with us and is still contagious. What has changed is our collective behaviour. Routines such as distancing and isolation that were alien to us in March have become institutionalised by June. We will draw on these institutionssome hierarchically imposed, some spontaneously developed, some resurrected, some not yet created - to guide our individual behaviour and to coordinate our collective activity into the future. However, two questions arise, one general and one more specific: how do we ensure that the rules continue to make sense to us in the complex and continually changing context of Covid-19? and how do we deal with the tensions inherent in maintaining the social distance rule in the short run-when we may feel buoyant and relatively safe-while staving off a resurgence of the virus in the medium term, ${ }^{14}$ and at the same time preserving what we can of our educational, economic, social and cultural heritage for the longer run ${ }^{15}$

Epilogue: Our meeting together post-lockdown turned out to be an enjoyable and positive occasion. Father and daughter spent thirty minutes in each other's company catching up on nearly three months of elapsed time during which much of consequence had taken place. It was clear that, although the rules forced us to keep

\footnotetext{
11 North (1990, p. 9) suggests that institutions change 'incrementally rather than in a discontinuous fashion' due to the 'embeddedness of informal constraints in societies'.

12 The scenes from northern Italy shown on TV and described in newspapers in March and April 2020 were shocking; for example, see Bonalume (2020).

13 A series of fines for breaching Covid-19 guidelines came into force in Ireland on 22nd November 2020 .

14 The virus surged again in Ireland in August 2020, with a consequent re-imposition of some restrictions and a partial lockdown of three counties (see Kenny 2020). A second lock-down of the entire country was imposed in October 2020.

${ }^{15}$ Loasby (1999, p. 46-47) discusses institutions as a response to uncertainty. However, he also warns that shared conventions persist because they give comfort and make action possible, but in time these same conventions may provide ineffective comfort and lead to unsatisfactory outcomes. Hence, a tension can exist between long run and short run outcomes.
} 
apart, they also provided a protocol that we were able to use to interact safely with each other. ${ }^{16}$ The awkwardness ${ }^{17}$ that I dreaded beforehand did not arise. We were actively developing a new norm of human behaviour. We do not yet know how long this new norm will last. Perhaps it will be gone by the end of August ${ }^{18}$; perhaps we will all live with the concept of social distancing for years to come.

\section{Compliance with ethical standards}

Conflicts of interest The author has no conflict of interests in respect of this article.

\section{References}

Bonalume, A. (2020). Devastated by coronavirus, did Bergamo's work ethic count against it? 6th April 2020, The Guardian. Available at https:/www.theguardian.com/world/commentisfree/2020/apr/06/ coronavirus-bergamo-work-ethic-lockdown. Accessed 3rd Sept 2020

Dixit, A., Skeath, S., \& McAdams, D. (2021). Games of strategy, 5th edition. New York: W.W. Norton.

Ginn, F., Beisel, U., \& Barua, M. (2014). Flourishing with awkward creatures: Togetherness, vulnerability and killing. Environmental Humanities, 4, 113-123.

Gordon, H. S. (1991). The history and philosophy of social science. London: Routledge.

Hodgson, G. (2006). What are institutions? Journal of Economic Issues, 40(1), 1-25.

Kenny, A. (2020). New restrictions for counties Kildare, Laois and Offaly, 7th August 2020, RTE. Available at https://www.rte.ie/news/2020/0807/1157957-govt-statement-covid/. Accessed 3rd Sept 2020

Loasby, B. (1999). Knowledge, institutions and evolution in economics. Oxon: Routledge.

North, D. (1990). Institutions, institutional change and economic performance. Cambridge: Cambridge University Press.

Roberts, M. (2020). Support bubbles: how do they work and who is in yours. BBC News Online. Available at https://www.bbc.com/news/health-52637354. Accessed 1 Dec 2020.

Searle, J. (2005). What is an institution? Journal of Institutional Economics, 1(1), 1-22.

Weick, K. (1993). The collapse of sensemaking in organizations: The Mann Gulch disaster. Administrative Science Quarterly, 38(4), 628-652.

Publisher's Note Springer Nature remains neutral with regard to jurisdictional claims in published maps and institutional affiliations.

\footnotetext{
16 See Hodgson (2006, p. 2) for a discussion on the stabilizing effect of a system of rules on human behaviour.

17 Ginn et al. (2014) see awkwardness in a generative light regarding it as a 'space between togetherness and distance' (p. 116) in which 'life's emergence' (p. 114) can flourish. In their study is of awkwardness between humans and non-humans they identify key constructs of togetherness and vulnerability. An interesting future direction is to consider their work in the light of awkwardness among humans. In this paper however I suggest that awkwardness can be mitigated by the human-created institutions that provide common ground and coordinate human activity.

18 This article was written in early June 2020. At the time of writing the ending of restrictions in Ireland in August 2020 was a possibility. However, this did not turn out to be so; authorities in Ireland now anticipate that the virus will be with us well into 2021. Note that the paper was revised in November 2020 as part of the peer review process.
} 